\title{
Laporan Kasus: Spontaneous Chronic Corneal Epithelial Defects (SCCED) Pada Kucing Domestik
}

\author{
Case Report Spontaneous Chronic Corneal Epithelial Defects (SCCED) In \\ Domestic Cat
}

\author{
Annisa Larasati ${ }^{*}$, Ajeng Aeka Nurmaningdyah², Aulia Azka Suradi K. ${ }^{1}$, Cheptien Winda \\ Virgiantari ${ }^{1}$, Icha Yung Aulia ${ }^{1}$, Hendra Setyo Nugroho ${ }^{1}$ \\ 1Program Studi Pendidikan Profesi Dokter Hewan, Fakultas Kedokteran Hewan, Universitas \\ Brawijaya \\ 2Laboratorium Klinik, Fakultas Kedokteran Hewan, Universitas Brawijaya \\ *e-mail : annisalrst@student.ub.ac.id
}

\begin{abstract}
ABSTRAK
Spontaneous Chronic Corneal Epithelial Defects (SCCED) merupakan penyakit mata yang berasal dari corneal ulcer yang tidak mengalami perbaikan dan timbulnya lapisan epitel yang melapisi kornea. Dari gejala klinis, pemeriksaan fisik dan pemeriksaan penunjang, kucing Belang diduga mengalami superficial corneal ulcer yang ditandai dengan adanya kekeruhan pada kornea dan diteguhkan dengan pemeriksaan penunjang berupa scimer tear test dan fluorecein test. Kucing Belang diberikan terapi obat berupa antibiotik topikal berupa gentamicin $0,3 \%$ untuk mencegah terjadinya infeksi sekunder dengan pemberian $3 \times$ sehari sebanyak 1 tetes dan juga atropine 1\% dengan pemberian $2 \times$ sehari sebanyak 1 tetes. Hasil evaluasi pengobatan selama 1 minggu, kucing Belang tidak mengalami perubahan pada korneal ulcer tersebut, mata tampak masih keruh dan terlihat adanya pembuluh darah. Berdasarkan hasil evaluasi tersebut, maka frekuensi pemberian obat ditingkatkan yaitu gentamicin tetes diberikan $4 \times$ sehari sebanyak 1 tetes dan atropine $1 \%$ diberikan $3 \times$ sehari sebanyak 1 tetes. Setelah 1 minggu, kucing Belang tidak menunjukkan adanya perbaikan, namun mengalami pembentukan lapisan diatas lapisan kornea dan didapatkan diagnosa akhir bahwa kucing Belang mengalami SCCED.
\end{abstract}

Kata kunci: Kucing, Mata, Ulkus kornea, SCCED

\begin{abstract}
Spontaneous Chronic Corneal Epithelial Defects (SCCED) is an eye disease originating from corneal ulcers that do not undergo repair and the growth of the epithelial layer lining the cornea. From the clinical symptoms, physical examination and supporting examinations, it is suspected that Belang's cat has a superficial corneal ulcer which is indicated by the presence of cloudiness in the cornea and confirmed by supporting examinations in the form of a scimer tear test and fluorescent test. Belang's cat was given drug therapy in the form of a topical antibiotic in the form of gentamicin $0.3 \%$ to prevent secondary infection by giving 1 drop 3 times a day and also 1\% atropine by administering 1 drop twice a day. The results of the treatment evaluation for 1 week, Belang's cat did not experience any changes in the corneal ulcer, the eyes were still cloudy and there were blood vessels. Based on the results of the evaluation, the frequency of drug administration was increased, namely gentamicin drops given 4 times a day as much as 1 drop and atropine $1 \%$ given 3 times a day as much as 1 drop. After 1 week, Belang's cat did not show any improvement but had a layer formation above the corneal layer and the final diagnosis was that Belang's cat had SCCED.
\end{abstract}




\section{PENDAHULUAN}

Kucing merupakan hewan kesayangan yang dapat merasakan sakit dan tidak nyaman ketika kesehatannya terganggu. Mata merupakan organ penting dan sangat sensitif dari tubuh makhluk hidup termasuk kucing. Abnormalitas fisiologi atau penyakit mata pada kucing yang sering terjadi antara lain seperti katarak, entropion, ektropion, glaukoma atau luka akibat trauma. Hal ini dapat disebabkan oleh beberapa faktor diantaranya posisi mata yang terletak di bagian cranial. Sehingga lebih besar kemungkinan mengalami terjadinya gangguan yang terjadi pada struktur mata. Kornea merupakan salah satu bagian yang sering mengalami kerusakan. Hal ini terjadi karena sebagian besar kornea terdiri dari protein sehingga rentan terhadap bahan kimia yang larut atau melewati protein. Kornea sangat tipis yang tebalnya kurang dari satu inci sehingga banyak penyakit yang dapat merusak ataupun menghancurkan membran tipis tersebut kemudian disebut dengan ulkus atau ulcer (Schoster, 2009). Cornea ulcer atau ulkus kornea sering terjadi akibat trauma. Selain trauma, ulkus kornea juga terjadi akibat infeksi, alergi trichiasis, enteropion, dan kurangnya air mata. Corneal ulcer yang tidak mengalami perbaikan maka akan timbul lapisan epitel yang melapisi kornea yang disebut Spontaneous Chronic Corneal Epithelial Defects (SCCED).

\section{STUDI KASUS}

\section{Sinyalamen}

Nama hewan belang, jenis hewan kucing, ras domestik short hair, umur 3 bulan, jenis kelamin betina, dan warna hitam coklat seperti pada Gambar 1.

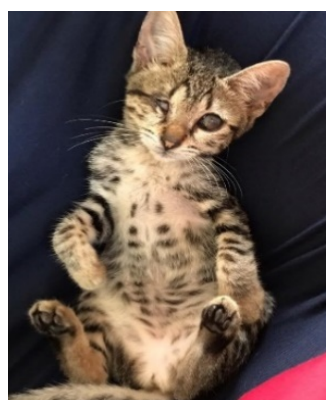

Gambar 1. Kucing Belang 


\section{Anamnesa}

Kucing Belang merupakan kucing liar yang ditemukan oleh salah satu anggota kelompok kami. Pada saat ditemukan kondisi kucing Belang cukup sehat, hanya saja pada bagian mata dexter tidak terdapat adanya bola mata sedangkan pada mata sebelah sinister korneanya terlihat keruh.

\section{Pemeriksaan Fisik}

Pemeriksaan fisik dilakukan pada kucing Belang meliputi, pemeriksaan fisik secara umum, kulit dan rambut, kepala dan leher, hidung dan sinus, telinga, kelenjar limfa, pernafasan, sirkulasi, abdomen dan pencernaan, urogenital, syaraf dan ekstremitas. Hasil pemeriksaan fisik pada Kucing Belang didapatkan suhu tubuh normal yaitu $38,1^{\circ} \mathrm{C}$, kemudian pada pemeriksaan frekuensi pernafasan hasilnya 36 kali/menit, frekuensi denyut jantung 148 kali/menit. Membran mukosa dan selaput lendir berwarna pink. Saat dilakukan pemeriksaan CRT dan turgor didapatkan hasil tidak lebih dari 2 detik. Pada mata sebelah dexter Kucing Belang terdapat discharge dan mata sebelah sinister tampak keruh.

\section{Pemeriksaan Penunjang}

Untuk meneguhkan diagnosa, dilakukan pemeriksaan pada mata yaitu: vision test, refleks test, tear test dan staining test. Pemeriksaan yang dilakukan hanya pada mata sinister karena pada mata bagian dexter congenital micropthalmia. Vision test bertujuan untuk melihat respon visual terhadap adanya gertakan (manace response), adanya reflek visual dalam mengikuti objek (cotton ball test), dan adanya reflek visual dalam menapakkan kaki pada suatu permukaan (visual placing reflex). Pada ketiga pemeriksaan ini tidak adanya kelainan pada mata bagian sinister kucing Belang. Pada pemeriksaan reflek mata siniter kucing belang terdiri dari, PLR (pupillary light reflex), dazzle reflex, palpabre reflex, dan corneal reflex tidak diremukan adanya kelainan pada keempat pengujian.

$$
\text { Schirmer test merupakan }
$$
pemeriksaan mata yang bertujuan untuk mengukur produksi air mata. Test ini 
menggunakan strip kertas schirmer yang berupa pita kertas dengan lebar $\pm 6 \mathrm{~mm}$. Pada pemeriksaan schirmer tear test yang dilakukan pada kucing Belang didapatkan hasil sebesar $5 \mathrm{~mm} /$ menit pada mata sebelah sinister. Hal tersebut menandakan bahwa kondisi mata sebalah sinister kucing Belang kering. Kondisi mata yang kering dapat memicu munculnya berbagai penyakit.

Tes fluorescein berfungsi untuk mendeteksi dan mengetahui adanya perlukaan atau abrasi pada permukaan kornea serta menentukan letaknya. Pada pemeriksaan fluoroscein yang dilakukan pada kucing Belang menunjukkan adanya pewarnaan pada bagian kornea lateral mata sebelah sinister pada Gambar 1. Larutan fluoroscein akan menempel atau tertinggal pada area yang mengalami kerusakan atau terdapat luka.

\section{Diagnosa}

Berdasarkan hasil pemeriksaan fisik dan pemeriksaan penunjang terhadap kucing Belang berupa adanya pewarna fluorescein yang tertinggal di kornea mata sinister kucing Belang. Diagnosa dapat disimpulkan bahwa pada mata sinister kucing Belang terdapat ulkus yang kemudian dapat disebut dengan corneal ulcer.

\section{Terapi}

Tujuan terapi dari corneal ulcer adalah menghilangkan penyebab awal dan untuk merangsang regenerasi spontan kornea, mencegah infeksi, dan menekan spasm ciliary. Terapi dimulai dengan menghilangkan semua faktor mekanik yang menyebabkan iritasi kornea, seperti benda asing, silia ektopik, entropion, trichiasis, distichiasis, dll. Terapi yang diberikan pada kucing Belang yaitu terapi dengan menggunakan obat. Obat yang digunakan merupakan obat golongan antibiotik dan agen midriatik. Antibiotik yang digunakan yaitu gentamicin sulfate $0,3 \%$. Selain menggunakan antibiotik, kucing Belang juga diterapi dengan menggunakan atropin sulfate $1 \%$ yang merupakan agen midriatik. 
Pemberian pertama yaitu gentamisin tetes $3 x$ sehari sebanyak 1 tetes dan juga atropine $1 \%$ dengan pemberian $2 x$ sehari sebanyak 1 tetes selama 7 hari. Setelah evaluasi dan tidak adanya perkembangan frekuensi pemberian ditingkatkan menjadi gentamicin tetes diberikan $4 \mathrm{x}$ sehari sebanyak 1 tetes dan atropine 1\% diberikan 3x sehari sebanyak 1 tetes selama 7 hari.

\section{PEMBAHASAN}

Pemeriksaan yang dilakukan hanya pada mata sinister karena pada mata bagian dexter mengalami congenital micropthalmia. Congenital microphtlamia unilateral adalah kondisi dimana salah satu bola matanya mengalami abnormal ukuran, kombinasi dari kecilnya jaringan palparae dan orbit, tidak adanya pengobatan yang dilakukan (Esson, 2015). Hasil pemeriksaan vision test pada mata sinister menunjukkan adanya respon visual pada gertakan (manace response), adanya reflek visual dalam mengikuti objek (cotton ball test) dan adanya refleks visual dalam menapakkan kaki pada suatu permukaan (visual placing reflex).

Pengujian PLR yaitu untuk melihat respon pupil saat disinari dengan sumber cahaya, intensitas cahaya yang lebih besar menyebabkan miosis karena cahaya yang masuk lebih sedikit, sedangkan intensitas cahaya yang rendah menyebabkan midriasis karena cahaya lebih banyak masuk. Sedangkan pada dazzle test untuk melihat reflek dari penutupan kelopak mata saat diberi sumber cahaya. Palpebre reflex (blink reflex), diuji dengan sentuhan ringan dan akan menghasilkan penutupan kelopak mata. Dan pada corneal reflex adalah salah satu refleks paling sensitif di otak tubuh dan tujuannya adalah untuk melindungi mata. Refleks kornea, diuji dengan menyentuh kornea perifer dengan kapas yang steril hasil untuk melihat retraksi bola mata dan penutupan kelopak mata (Gelatt, 2013).

Untuk mengetahui apakah air mata yang diproduksi cukup maka dilakukan pemeriksaan Schirmer Tear Test (STT) dengan hasil 5mm/ menit yang dapat 
dilihat pada Gambar 2. Cara penggunaan yaitu strip schirmer dapat dipegang dengan menggunakan tangan atau dengan menggunakan forceps kering dan ujung strip yang steril diletakkan pada kantung konjungtiva ventral, jaraknya satu pertiga dari canthus lateral. Setelah strip ditempelkan pada mata pasien, mata tersebut ditutup dan dibiarkan selma satu menit. Kemudian diukur panjangnya kertas yang terbasahi. Nilai STT rendah pada kucing harus diinterpretasi dengan hati-hati bersama dengan tanda-tanda klinis karena kisaran nilai-nilai pada kucing normal sangat lebar. Nilai STT pada kucing dewasa normal bervariasi dari $14,3 \pm 4,7 \mathrm{~mm} /$ menit hingga 16,92 $\pm 5,73 \mathrm{~mm}$ / menit (Cullen et al., 2005). Nilai normal dari hasil schirmer test pada kucing yaitu kertas yang terbasahi sepanjang 10 - $20 \mathrm{~mm}$. Jika strip yang terbahasahi kurang dari $10 \mathrm{~mm}$ mengindikasikan kondisi mata yang kering karena terdapat kelainan produksi air mata (Gellat et al., 2013).
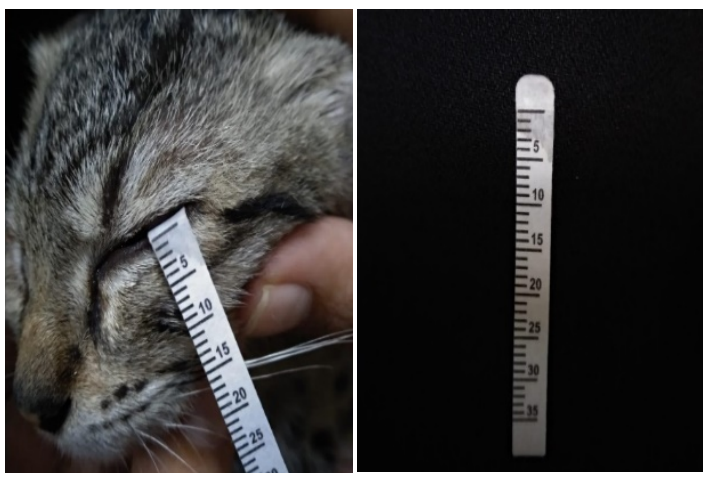

Gambar 2. STT pada mata sinister

Selain itu juga dilakukan pemeriksaan fluorescent test pada kucing Belang untuk mendeteksi adanya bagian epitelium kornea yang hilang/ erosi kornea (Gelatt, 2013). Pemeriksaan ini dilakukan dengan menetaskan fluorescein tetes atau dapat menggunkan fluorescein strip yang telah dibasahi terlebih dahulu dengan menggunakan larutan akuades steril kemudian ditempelkan pada mata. Larutan fluorescein yang berwarna jingga akan menyebar ke seluruh permukaan mata. Setelah itu mata dibilas dengan menggunakan larutan normal salin yang berfungsi untuk membersihkan larutan fluoroscein. Kemudian mata dapat diamati dengan menggunakan atau ophtalmoscope pada ruangan yang gelap. Interpretasi dari fluorescent test pada mata sinister Kucing 
Belang yaitu terdapat cairan sodium fluorescein yang tertinggal pada stroma yang menandakan adanya erosi pada sel epitel Gambar 3. Fluoroscein memiliki sifat larut air sehingga akan terabsorbsi pada stroma kornea yang hidrofilik pada kornea yang rusak (Stades, 2007). Berdasarkan hasil uji fluorescent test diagnosa tentatif pada mata sinister kucing belang yaitu ulkus kornea/ kornea ulser pada bagian superfisial.

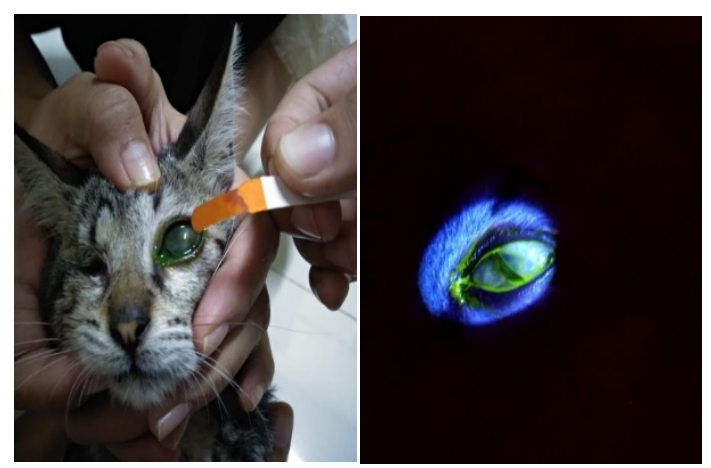

Gambar 3. Fluorescent test pada mata sinister

Kornea ulser merupakan kondisi dimana terjadi erosi baik secara superficial maupun dalam pada kornea dengan gangguan kehilangan jaringan. Kornea ulser dapat disebabkan oleh iritasi mekanis (rambut sendiri, entropion, distichiasis, silia ektopik, aplasia palpebral, benda asing, trauma), infeksi (virus, penyakit saluran pernafasan atas), kornea yang kering (KCS, pengobatan atropin dan anastesi ketamin) (Stades, 2007). Penanganan dimulai dengan menghilangkan semua faktor mekanik yang menyebabkan iritasi kornea kemudian dilanjutkan dengan pemberian obat. Kornea ulser memiliki kontraindikasi terhadap obat golongan kortikosteroid dan anastesi lokal karena dapat menghambat epitelisasi.

Pengobatan yang diberikan pada Kucing Belang yaitu menggunakan antibiotik topikal (tetes) yaitu gentamicin $0.3 \%$ dengan pemberian $3 x$ sehari sebanyak 1 tetes dan atropine 1\% dengan pemberian $2 \mathrm{x}$ sehari sebanyak 1 tetes. Tujuan pemberian antibiotik untuk mencegah infeksi sekunder karena epitel yang berfungsi sebagai penghalang mengalami erosi (Little, 2011). Terapi yang diberikan sudah sesuai dengan pernyataan (Stades, 2007) yaitu, dengan pilihan obat antibiotik 4-6 kali sehari, minyak vitamin A 4 kali sehari, dan 1\% atropine 2-4 kali sehari (jika terjadi uveitis anterior). Setelah 1 minggu dan dilakukan evaluasi keberhasilan 
pengobatan menunjukkan tidak adanya perubahan yang terlihat pada kornea ulser tersebut, mata masih tampak keruh dan terlihat adanya pembuluh darah. Berdasarkan hasil evaluasi tersebut, maka frekuensi pemberian obat ditingkatkan menjadi $4 \mathrm{x}$ sehari sebanyak 1 tetes untuk gentamicin dan $3 x$ sehari sebanyak 1 tetes atropine $1 \%$.

Obat yang digunakan berupa Gentamicin merupakan antibiotik golongan aminoglikosida yang menghambat sintesis protein. Memiliki sifat bakterisidal dan memiliki mekanisme tergantung pada konsentrasi. Pemberian gentamicin digunakan sebagai antibiotik profilaksis yang bertunjuan untuk mencegah adanya infeksi sekunder pada kornea. Pada penggunaan untuk mata gentamicin dapat digunakan sebanyak 1 tetes diberikan selama 6 - 8 jam (Gellat et al., 2013; Ramsey, 2017). Sedangkan obat agen midriatik yang digunakan adalah atropine sulfat. Cara kerja atropin yaitu dengan memblokir aktivitas dari asetilkolin pada reseptor muskarinik di ujung terminal sistem parasimpatik, mengembalikan efek parasimpatis dan memproduksi midriasis. Atropin menghambat respon pada otot sfingter iris dan otot akomodasi badan ciliar terhadap perangsangan kolinergik. Atropin dalam sediaan tetes memiliki rasa yang sangat pahit sehingga dapat menyebabkan hipersalivasi pada kucing. Pemberian obat ini sebanyak, 1 tetes q8 - 12 jam agar terjadi midriasis (Ramsey, 2017; Stades, 2007).

Pasien tidak menunjukkan perbaikan setelah dilakukan peningkatan frekuensi obat selama satu minggu, namun mengalami pembentukan lapisan di atas kornea pada Gambar 4. Lapisan tersebut dicurigai sebagai epitel yang terbentuk sebagai respon persembuhan dari korneal ulcer namun mengalami kegagalan melekat pada stroma yang mendasarinya. Menurut literatur, keadaan ini disebut dengan Spontaneous Chronic Corneal Epithelial Defects (SCCED). SCCED merupakan erosi epitel kronis yang gagal dalam melakukan proses penyembuhan lukanya secara normal. 
Terjadinya SCCED pada hewan kemungkinan adalah akibat adanya trauma kornea superficial (Gelatt et al., 2013).

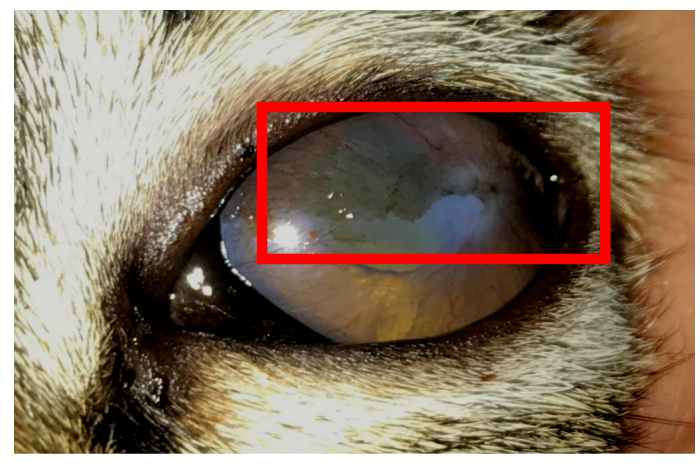

Gambar 4. Terbentuknya epitel diatas lapisan kornea

Patofisiologi SCCED masih belum sepenuhnya dijelaskan. Menurut Bentley et al (2001), SCCED terjadi pada ulkus kornea superficial yang tidak diketahui penyebabnya dan tidak mengalami persembuhan dalam waktu 7 hari. SCCED dapat terjadi ketika tidak adanya membran basal pada kucing tersebut, hal itu menunjukkan bahwa kompleks adhesi dan/atau komponen matriks ekstraseluler dari pasien ini tidak normal sebelum terjadinya erosi atau sel epitel tersebut memang tidak membentuk perlekatan saat proses penyembuhan luka (cacat pada adhesi stroma epitel). Epitel yang berdekatan dengan daerah lesi menunjukkan perlekatan yang buruk pada stroma yang mendasarinya terdapat pada Gambar 5.

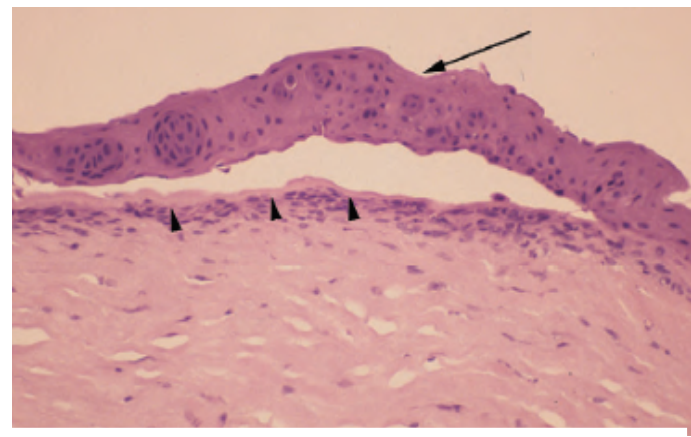

Gambar 5. Epitel terbentuk tidak menempel dengan dasar stroma (SCCED) (Gelatt et al., 2013).

Spontaneous Chronic Corneal Epithelial Defects (SCCED) dengan margin epitel yang tidak ter-adhesi dapat dihilangkan dengan aplikator kapas (epitel yang sehat akan tetap melekat setelah digosok dengan lembut). Debrimen tersebut dilakukan setelah pemberian anastesi topikal..Tindakan lain yang dapat dilakukan untuk menangani SCCED yaitu dengan melakukan keratotomi. Selain melakukan penanganan dengan cara operasi, SCCED juga dilakukan pengobatan menggunakan antibiotik profilaksis topikal seperti tobramycin dan gentamicin, diberikan satu sampai dua kali sehari untuk mencegah dari infeksi sekunder. Jika sudah 
terjadi infeksi kornea, maka antibiotik yang dapat diberikan adalah fluoroquinolone. Spontaneous Chronic Corneal Epithelial Defects (SCCED) umumnya akan mengalami persembuhan dalam waktu 7-10 hari dengan melakukan terapi seperti diatas. Bila hasil fluorescein sudah negatif, langkah selanjutnya adalah memberikan terapi singkat steroid topikal untuk meminimalkan vaskularisasi dengan bekas luka kornea yang kecil sehingga tidak megganggu penglihatan (Bantley, 2011).

\section{KESIMPULAN}

Spontaneous Chronic Corneal Epithelial Defects (SCCED) terjadi karena tidak adanya perbaikan lapisan kornea dari korneal ulser dan terjadi pembentukan lapisan epitel diatas kornea. Proses ini terjadi karna tidak membentuk perlekatan saat proses Penyembuhan luka (cacat pada adhesi stroma epitel). Sehingga, pengobatan antibiotika dan anti midriatik yang diberikan tidak menunjukkan perbaikan. Kelanjutan pengobatan yang memungkinkan pada kondisi tersebut membutuhkan tindakan operasi.

\section{DAFTAR PUSTAKA}

Bentley E, Abrams G. A, and Covitz D. 2001. Morphology and Immunohistochemistry of Spontaneous Chronic Corneal Epithelial Defects (SCCED) in Dogs. Invest Ophthalmol Vos Sci 42 (10), 2262-2269.

Bentley, E. 2011. What to Do When Ulcers Won't Heal : Management of Superficial, Chronic Corneal Epithelial Defects in Dogs. World Small Animal Veterinary Association World Congress Proceedings

Cullen, C.L., et al. 2005. Tear film breakup times in young healthy cats before and after anesthesia. Veterinary Ophthalmology, 8, 159-165.

Esson, D.W. 2015. Clinical Atlas of Canine and Feline Ophthalmic Disease. USA: Willey Blackwell

Gelatt, K., B. Gilger, T. Kern. 2013. Veterinary Ophthalmology. Fifth Edition Volume I and Volume II. Wiley-Blackwell.

Little, S. 2011. The Cat Clinical Medicine and Management. UK: Saunders

Ramsey, I. 2017. Small Animal Formulary 9th edition canine and feline: BSAVA

Schoster J. V. 2009. Complicated Corneal Ulcers Microbial Keratitis. Univerisity of Wisconsin USA.

Stades, F.C. 2007. Ophthalmology for The Veterinary Practitioner. Germany: Schlutersche 